\title{
Comparison of Galactokinase Induction in Protoplasts and Intact Bacteria of Bacillus megaterium 216
}

\author{
By P. J. AINSWORTH AND G. COLEMAN* \\ Department of Biochemistry, The University, Sheffield, SIo 2TN \\ (Accepted for publication I7 July 1970)
}

\begin{abstract}
SUMMARY
Bacillus megaterium $2 \mathrm{I} 6$ was induced with D-galactose to form galactokinase (EC 2.7.1.6) in amounts comparable with those induced in Escherichia coli $\mathrm{K} \mathrm{I} 2$. When compared with the basal level, the increase was 20 times greater than in $E$. coli.

The greater the concentration of D-galactose, the greater the production of galactokinase in both protoplasts and whole bacteria. In each case the maximum amount of enzyme was induced by $5 \mathrm{mM}$ D-galactose. D-Fucose, a gratuitous inducer, produced approximately half the specific activity of enzyme in protoplasts as D-galactose at any particular concentration. The yield of enzyme in the presence of an optimal concentration of D-galactose was increased when the medium was fortified with low concentrations of casein hydrolysate. The specific activities of galactokinase induced in protoplasts and in whole bacteria were respectively $148 \%$ and $37 \%$ greater in the presence of $0.01 \%$ casein hydrolysate.

The maximum specific activity of galactokinase achieved after induction of protoplasts for $60 \mathrm{~min}$. was 3.7 units/mg. protein compared with 12.5 units/ $\mathrm{mg}$. protein in whole bacteria. However, over the first $15 \mathrm{~min}$. after the addition of inducer the same specific activity of galactokinase was achieved in protoplasts as in whole bacteria.
\end{abstract}

\section{INTRODUCTION}

In 1955 the induced formation of arabinokinase in Bacillus subtilis protoplasts (Wiame, Storck \& Vanderwinkel, 1955) and $\beta$-galactosidase in Bacillus megaterium protoplasts (Landman \& Spiegelman, 1955; McQuillen, 1955) were reported. Subsequently, a few isolated reports of enzyme induction in Escherichia coli spheroplasts appeared (McQuillen, I960). However, over the years surprisingly little work has been done on these potentially useful sources of cell-free enzyme-forming systems. The only such study has been made by Kiho \& Rich (I964), who isolated a cell-free system for $\beta$-galactosidase formation after induction of $E$. coli spheroplasts with methyl- $\beta$ thiogalactopyranoside.

The present study was undertaken with the object of developing a model system in which the factors which limit the cell-free synthesis of a specific protein could be studied. It was considered desirable to have an intact organized system which could be converted into a cell-free extract with the minimum delay and by the gentlest possible treatment. These conditions were fulfilled by a Bacillus megaterium system which readily forms stable protoplasts which can be induced to form galactokinase (EC 2.7.I.6), a relatively low molecular weight enzyme for which there is a sensitive

\footnotetext{
* Present address: Department of Biochemistry, The University, Nottingham, NG7 2RD.
} 
and simple assay procedure. Further, these galactokinase-forming protoplasts can be readily and rapidly disrupted by osmotic lysis to give cell-free preparations. The only detailed studies on galactokinase induction in bacteria have been restricted to whole cells of Escherichia coli (Paigen, 1963; Buttin, 1968; Wilson \& Hogness, 1969).

\section{EXPERIMENTAL}

Organism. The bacterial strain used was Bacillus megaterium 216 from the collection of Professor G. Ivanovics, The Medical University, Szeged, Hungary. Samples of the freeze-dried bacteria were subcultured at 3 month intervals on basal medium (see below), containing $20 \mathrm{~mm} \mathrm{D}$-glucose, streaked on nutrient agar slopes and incubated at $30^{\circ}$ for $24 \mathrm{~h}$. The resulting cultures were used as sources of day-to-day inocula. Escherichia coli $\mathrm{K} 12$ strain W 1485 , used in the comparative studies, was kindly provided by Dr J. R. Guest, Department of Microbiology, University of Sheffield. It was subcultured on to nutrient agar and incubated at $30^{\circ}$ for $24 \mathrm{~h}$. immediately before use.

Growth conditions. The bacteria were grown in a medium which was essentially that of Buttin (1963), and consisted of a defined salts solution (referred to as the 'basal medium') together with $20 \mathrm{~mm}$ D-glucose unless otherwise stated. The basal medium consisted of $\mathrm{KH}_{2} \mathrm{PO}_{4}, 0 . \mathrm{I} \mathrm{M} ; \mathrm{MgSO}_{4} \cdot 7 \mathrm{H}_{2} \mathrm{O}, 0.8 \mathrm{mM} ;\left(\mathrm{NH}_{4}\right)_{2} \mathrm{SO}_{4}, \mathrm{I} 5 \mathrm{mM} ; \mathrm{FeSO}_{4} \cdot 7 \mathrm{H}_{2} \mathrm{O}$, $0.01275 \mathrm{mM}$; 'trace metal ion' solution, $0.5 \mathrm{ml}$./1. (Coleman \& Elliott, I965); $\mathrm{pH} \mathrm{7.2.}$

The medium ( $50 \mathrm{ml} . / 250 \mathrm{ml}$. conical flask) was inoculated from a slope and incubated for $18 \mathrm{~h}$. at $30^{\circ}$ in a Gyrotory incubator-shaker (model G25, New Brunswick Scientific Co. Inc.) operating at 240 oscillations/min. The resulting culture was then diluted tenfold with fresh nonsterile medium in a 21 . conical flask and incubated (ca. 4 h.) until $E_{600}^{1 \mathrm{~cm} .}=0.8$.

Washed bacteria and protoplast experiments. Cultures at $E_{600}^{1 \mathrm{em} .}$ of 0.8 were centrifuged at $4500 \mathrm{~g}$ for $2 \mathrm{~min}$. and the bacterial pellet washed with fresh basal medium by centrifuging. For the experiments with whole bacteria, the organisms were resuspended to the initial density in basal medium plus the required carbon and complex nitrogen sources, and samples of the suspension $(40 \mathrm{ml} / 250 \mathrm{ml}$. flask) were shaken at 240 oscillations $/ \mathrm{min}$. at $30^{\circ}$.

Protoplast suspensions were prepared from the washed bacteria resuspended to the initial density in basal medium containing sucrose $(20 \%$ w/v) and lysozyme (B.D.H. Chemicals Ltd; $5 \mathrm{mg} . / 100 \mathrm{ml}$.) and shaken (200 ml. suspension $/ 21$. flask) at $30^{\circ}$ at I 20 oscillations/min. Protoplast formation was completed in $15 \mathrm{~min}$. and the preparation was used immediately.

Preparation of cell-free extracts. Bacteria and protoplasts were washed prior to disruption; this procedure removed D-galactose, which if present interfered in the assay of galactokinase. Bacteria from $40 \mathrm{ml}$. of suspension were harvested by centrifuging at $4500 \mathrm{~g}$ for $2 \mathrm{~min}$., resuspended in fresh basal medium and then centrifuged again. The pellet was resuspended in $2.5 \mathrm{ml}$. of supplemented buffer solution; this contained $\mathrm{K}_{2} \mathrm{HPO}_{4}, 0.02 \mathrm{M}$; dithiothreitol, I.5 mM; EDTA, I mM; bovine serum albumin $100 \mu \mathrm{g} . / \mathrm{ml}$; adjusted to $\mathrm{pH} 7 \cdot 4$ with glacial acetic acid (Gulbinsky \& Cleland, 1968). The bacteria were lysed by adding $\mathrm{I} \cdot 25 \mathrm{mg}$. lysozyme and allowing to stand at room temperature for $30 \mathrm{~min}$. Protoplasts were washed by layering $25 \mathrm{ml}$. batches of suspension on to $25 \mathrm{ml}$. ice-cold $30 \%$ (w/v) sucrose in basal medium and centrifuging at $4500 \mathrm{~g}$ for $10 \mathrm{~min}$. The protoplast pellet was lysed by shaking with 
$2.5 \mathrm{ml}$. of the supplemented buffer solution. The lysed bacteria or protoplasts were centrifuged at I I0,000 $\mathrm{g}$ for $45 \mathrm{~min}$. at $0^{\circ}$ and the supernatant fractions taken for the assay of galactokinase and protein.

Determination of galactokinase. Galactokinase was determined by a radiometric method adapted from the procedure of Sherman \& Adler (1963) by Gulbinsky \& Cleland (1968). Extracts of fully induced washed bacterial suspensions were diluted up to I20-fold and extracts of protoplasts tenfold with supplemented buffer solution to give preparations whose activity was in the range where there was a linear relationship between velocity of reaction and enzyme concentration.

Determination of protein. Extracts from washed bacteria contained sufficient protein to be estimated by the biuret method of Layne (1957). The protein content of protoplast extracts was less and was measured by the modified biuret method of Bürgi, Richterich \& Briner (1967).

Bacterial density determination. Bacterial densities were determined by measuring extinction at $600 \mathrm{~nm}$. in cuvettes with a $\mathrm{I} \mathrm{cm}$. light path.

Bacterial mass determination. Dry weights of washed bacteria were determined as described by Coleman \& Elliott (I962).

Casein hydrolysate. 'Oxoid' casein hydrolysate (acid) was used as a nitrogen supplement ('Oxoid' Division of Oxo Ltd, London E.C.4).

\section{RESULTS}

Comparison of galactokinase levels in Bacillus megaterium 216 and Escherichia coli $K I 2$

It was of interest to make an initial comparison between the levels of enzyme in Bacillus megaterium $2 \mathrm{I} 6$ and Escherichia coli $\mathrm{K} \mathrm{I} 2$ before and after induction with D-galactose. Whilst a low level of enzyme was detected in both the uninduced bacteria, in $B$. megaterium the level was less than one-tenth of that in $E$. coli. After induction with D-galactose (20 mM) comparable levels of enzyme were found in both organisms, the level in B. megaterium being $30 \%$ higher than in E. coli. However, due to the lower basal level in $B$. megaterium a 208 -fold increase in enzyme was observed on induction compared with a 13 -fold increase in $E$. coli.

\section{Stability of sucrose-stabilized protoplasts}

It was important to determine the period during which the protoplasts remained stable without evidence of spontaneous lysis. A sucrose-stabilized protoplast suspension in basal medium was induced by the addition of $20 \mathrm{~mm}$ D-galactose, and the time course of increase in galactokinase was followed together with the change in intracellular protein. There was a rapid increase in both protein and galactokinase during the first $60 \mathrm{~min}$. of incubation and thereafter levels of both fell, suggesting that after this period the protoplasts become unstable and start to lyse.

It was possible that lysis also occurred to a limited extent during the first $60 \mathrm{~min}$. but was not detected because of the masking effect of net increases in enzyme and protein. By expressing results in terms of specific activity, this possible source of error or experimental variation may be eliminated. 


\section{Effect of casein hydrolysate concentration}

The effect of casein hydrolysate on the induction of galactokinase in protoplasts was compared with its effect on induction in whole bacteria.

The addition of $0.005 \%$ casein hydrolysate to protoplasts induced with $5 \mathrm{~mm}$ D-galactose caused a doubling in specific activity of the enzyme (Table r). Increase in the casein hydrolysate concentration to $0.05 \%$ produced only a further $20 \%$ increase in the specific activity of galactokinase. In contrast, similar additions of casein hydrolysate $(0.005$ to $0.05 \%)$ had no effect on the specific activity of galactokinase in protoplasts induced with $5 \mathrm{mM}$ D-fucose (6-deoxy-D-galactose), a gratuitous inducer of galactokinase (Buttin, I963).

\section{Table I. Effect of casein hydrolysate as a nitrogen supplement on galactokinase formation}

\begin{tabular}{|c|c|c|c|}
\hline \multirow{3}{*}{$\begin{array}{c}\text { Casein hydrolysate } \\
\%\end{array}$} & \multicolumn{3}{|c|}{$\begin{array}{l}\text { Specific activity of galactokinase } \\
\text { (units/mg. protein) } \\
\text { in }\end{array}$} \\
\hline & \multicolumn{2}{|c|}{ Protoplasts induced by } & \multirow{2}{*}{$\begin{array}{l}\text { Whole bacteria } \\
\text { induced by } \\
20 \text { mM D-galactose }\end{array}$} \\
\hline & $5 \mathrm{~mm} \mathrm{D}$-fucose & $5 \mathrm{mM}$ D-galactose & \\
\hline 0.000 & $1 \cdot 92$ & $I \cdot 48$ & $16 \cdot 2$ \\
\hline 0.005 & $1 \cdot 96$ & 3.06 & 23.8 \\
\hline 0.010 & $I \cdot 92$ & $3 \cdot 73$ & $22 \cdot 0$ \\
\hline 0.050 & $I \cdot 85$ & 3.57 & $2 \mathrm{I} \cdot \mathrm{I}$ \\
\hline
\end{tabular}

Galactokinase was induced in whole bacteria by both $5 \mathrm{~mm}$ and $20 \mathrm{~mm}$ D-galactose in the absence of casein hydrolysate to give a specific activity three times greater than that achieved in protoplasts after the same incubation period of $I \mathrm{~h}$. The specific activity in whole bacteria was increased a further threefold after $3 \mathrm{~h}$. incubation with $20 \mathrm{mM}$ D-galactose. The effect of adding $0.005 \%$ casein hydrolysate under these latter conditions was to produce a further $37 \%$ increase in specific activity. Increase in the concentration of casein hydrolysate to $0.05 \%$ did not stimulate the formation of any more galactokinase.

A concentration of D-galactose of $20 \mathrm{~mm}$ was employed as inducer with whole bacteria in preference to $5 \mathrm{~mm}$ during a $3 \mathrm{~h}$. incubation since at the lower concentration all the D-galactose was metabolized, whilst at the higher concentration D-galactose was detectable in the medium at the end of the incubation.

\section{Effect of inducer concentration}

Studies of the effect of different concentrations of D-galactose and D-fucose on galactokinase induction in protoplasts showed that with both inducers the specific activity of the galactokinase increased with increase in inducer concentration, reaching a maximum at $3 \mathrm{mM}$ D-galactose and $5 \mathrm{~mm}$ D-fucose (Fig. $\mathrm{I} a$ ). Greater concentrations of inducer produced little change in specific activity of the enzyme. The maximum 
specific activity in the presence of D-galactose was twice that achieved in the presence of D-fucose. In whole bacteria induced with D-galactose similar characteristics were observed (Fig. I $b$ ), maximum activity being achieved at a concentration of $5 \mathrm{~mm}$; increasing the inducer concentration above this had no effect. However, in the presence of D-fucose the pattern was rather different; with $0.5 \mathrm{~mm}$ D-fucose the level of galactokinase activity was similar to the maximum amount induced by D-galactose. Further increase in D-fucose concentration from 0.5 to $20 \mathrm{mM}$ resulted in a doubling of the specific activity of galactokinase.

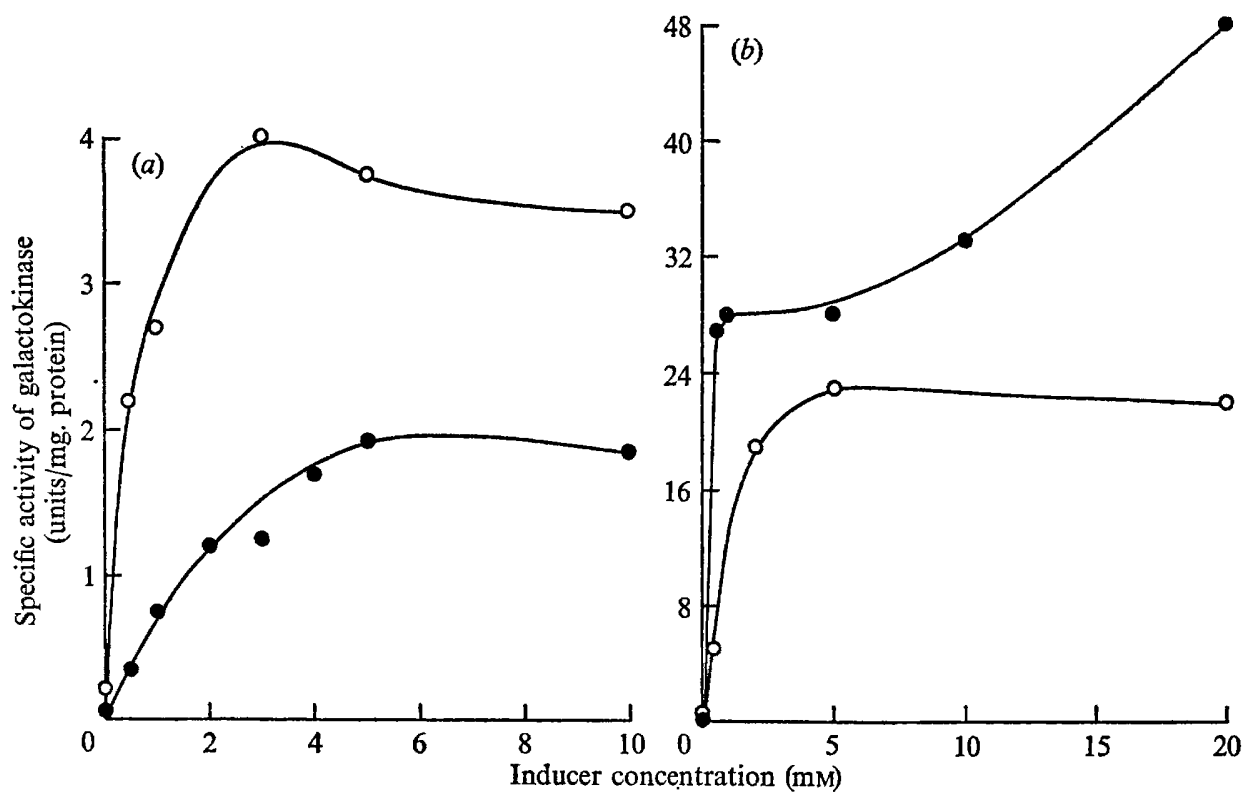

Fig. 1. Effect of inducer concentration on the induction of galactokinase in $(a)$ protoplasts and (b) whole bacteria. Protoplasts were incubated for $60 \mathrm{~min}$. and whole bacteria for $3 \mathrm{~h}$. in basal medium containing $0.01 \%$ casein hydrolysate and different concentrations of D-galactose $(O)$ or D-fucose $(O)$.

\section{Progress of galactokinase formation}

The progress of galactokinase induction was studied in the presence of basal medium containing $0.01 \%$ casein hydrolysate and D-galactose or D-fucose at a concentration of $5 \mathrm{~mm}$ for protoplasts and $20 \mathrm{~mm}$ for whole bacteria.

In the presence of D-galactose the galactokinase and protein content of the protoplasts increased and reached a maximum at $60 \mathrm{~min}$., at which time maximum specific activity was also achieved (Fig. $2 a$ ). On further incubation both protein and galactokinase activity fell, indicating that the protoplasts were becoming unstable and lysing.

In the presence of the gratuitous inducer D-fucose total galactokinase and specific activity again reached a maximum after $60 \mathrm{~min}$. (Fig. $2 b$ ), and as expected protein content changed relatively little over the period of the experiment. In this experiment the development of protoplast instability was less pronounced than in the presence of D-galactose, and specific activity remained relatively constant at about half the maximum level achieved with the nongratuitous inducer. 
The progress of galactokinase induction in whole bacteria (Fig. $3 a, b$ ) produced the expected patterns of increase in bacterial density over $3 \mathrm{~h}$. in the presence of D-galactose and little change in bacterial density in the presence of $\mathrm{D}$-fucose. This resulted in specific activities being at least twofold greater throughout the $3 \mathrm{~h}$. incubation for the D-fucose-induced bacteria.

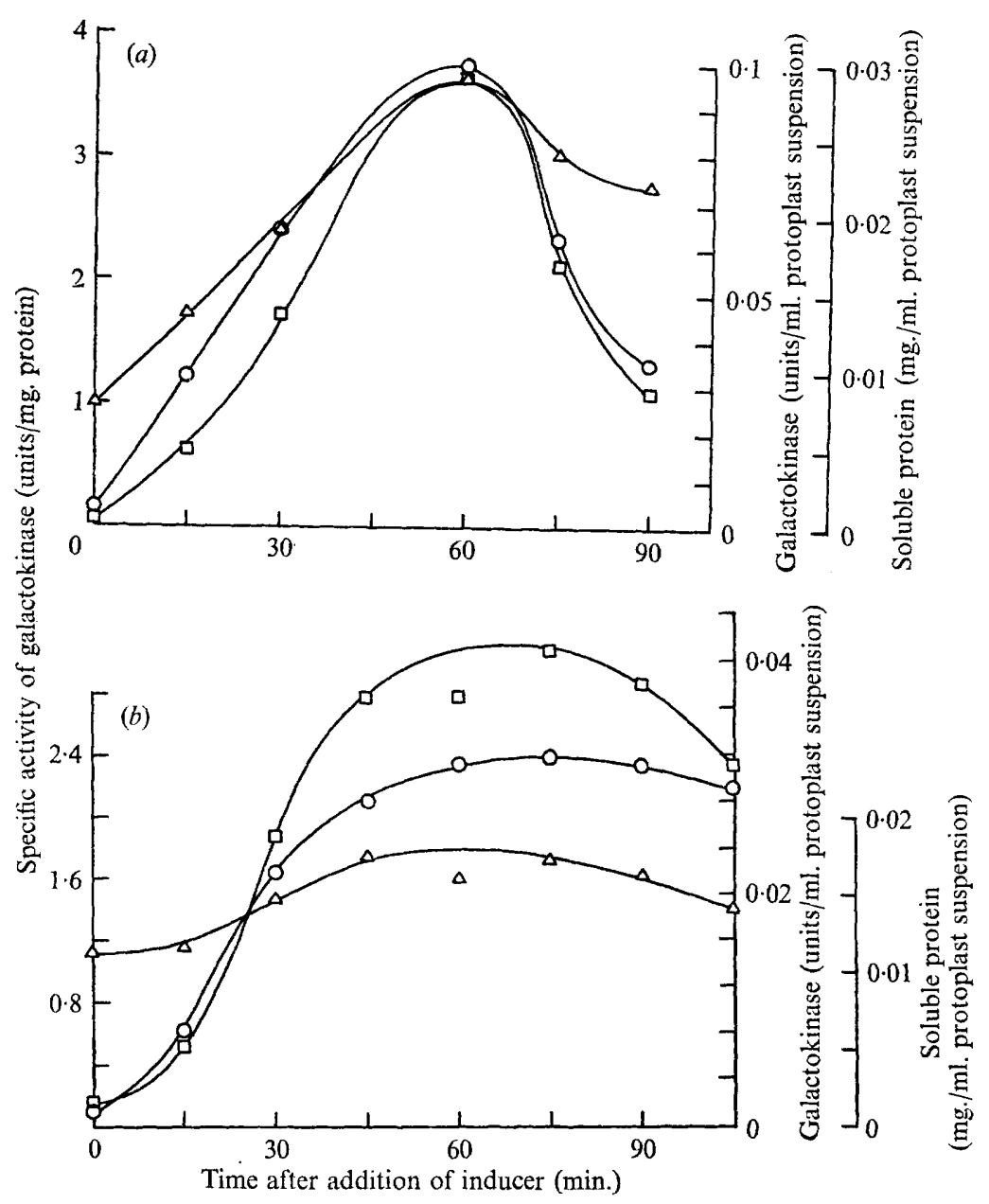

Fig. 2. Progress of galactokinase induction in protoplasts by $(a) \mathrm{D}$-galactose and $(b) \mathrm{D}$-fucose. Protoplasts were incubated in basal medium containing $0.01 \%$ casein hydrolysate, $20 \%$ $(\mathrm{w} / \mathrm{v})$ sucrose and inducer at a concentration of $5 \mathrm{~mm}$. Samples were taken at intervals for galactokinase $(\square)$ and soluble protein $(\triangle)$ assay. Specific activities of galactokinase $(O)$ were calculated from the data obtained.

The progress curves for galactokinase formation induced by D-galactose in protoplasts (Fig. 2a) and in whole bacteria (Fig. $3 a$ ) show that the specific activity of the enzyme increased by the same amount during the first $15 \mathrm{~min}$. after induction. Thereafter the specific activity in whole bacteria increased more rapidly, being $50 \%$ higher after $30 \mathrm{~min}$. and three times higher after I h. It was of interest to establish whether 
this difference was due to more favourable external conditions imposed on whole bacteria compared with protoplasts or whether it was related to a more highly developed enzyme-forming machinery in whole bacteria.

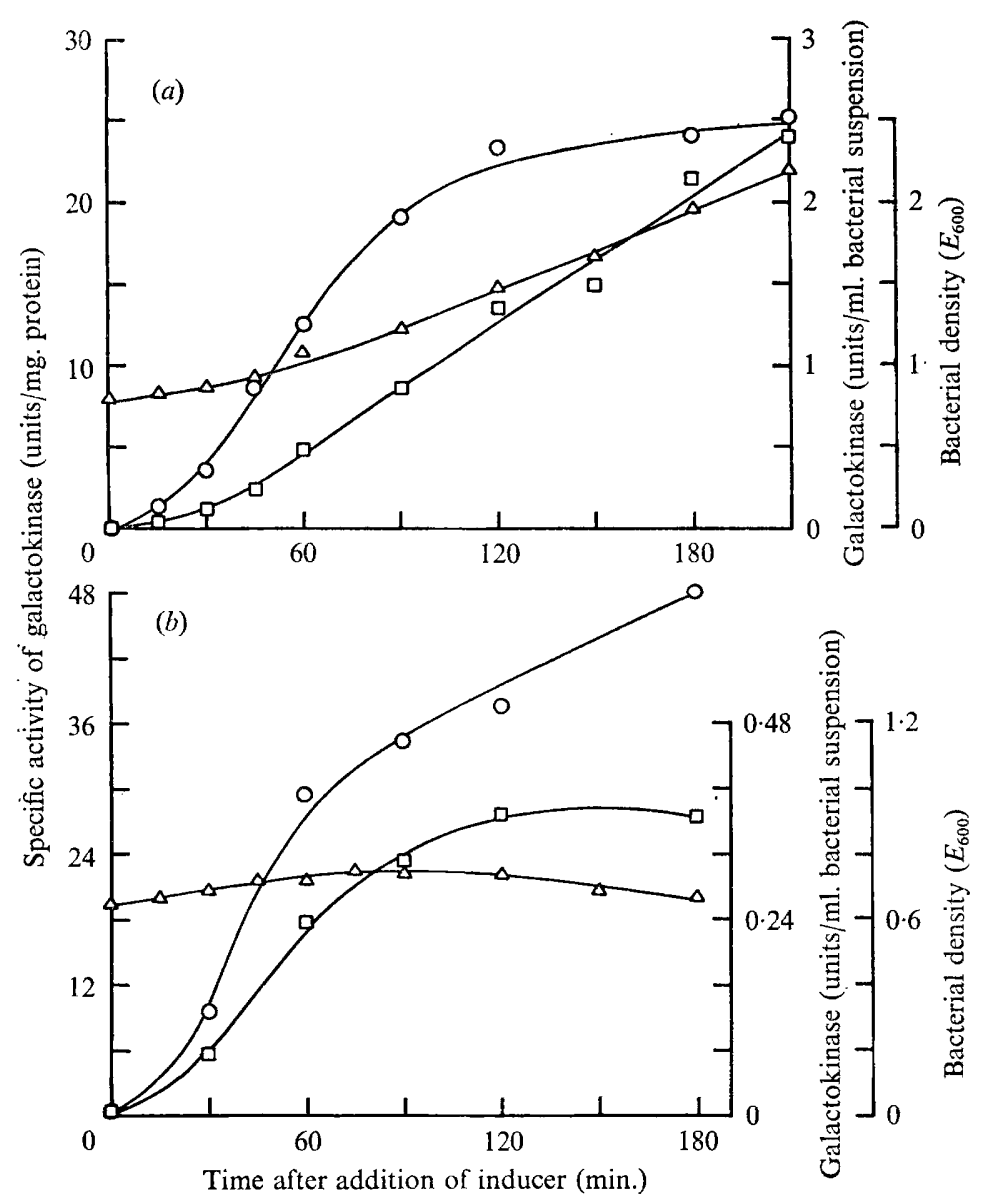

Fig. 3. Progress of galactokinase induction and change in bacterial density in the presence of $(a) \mathrm{D}$-galactose and $(b) \mathrm{D}$-fucose. Intact bacteria were incubated in basal medium containing $0.01 \%$ casein hydrolysate and inducer at a concentration of $20 \mathrm{~mm}$. At different times during the incubation bacterial density was determined in terms of extinction at $600 \mathrm{~nm} .(\triangle)$ and samples were taken for determination of total galactokinase $(\square)$ and its specific activity $(O)$.

The addition of $20 \%(\mathrm{w} / \mathrm{v})$ sucrose to a suspension of whole bacteria, in the presence of $5 \mathrm{~mm}$ D-galactose caused a $50 \%$ reduction in specific activity of the enzyme over a 60 min. incubation (Fig. 4). Reduction of the shaking rate to that which was optimal for maintaining protoplast stability further reduced the specific activity to $66 \%$ of that achieved in protoplasts under similar conditions. 


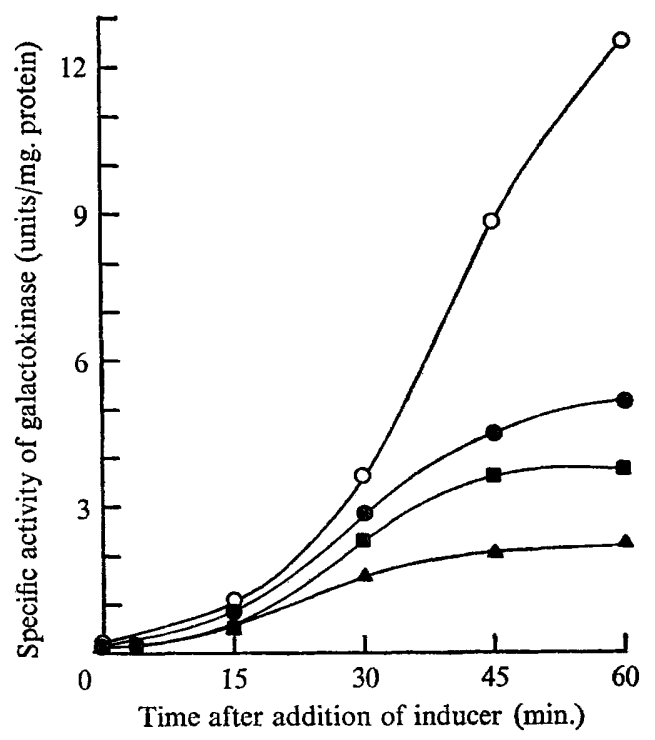

Fig. 4. Effect of incubating washed bacteria under the conditions employed for the induction of galactokinase in protoplasts. The increase in specific activity of galactokinase in whole bacteria shaken at 240 oscillations/min. in the presence $(O)$ and absence $(O)$ of $20 \%(w / v)$ sucrose was compared with whole bacteria in the presence of $20 \%(\mathrm{w} / \mathrm{v})$ sucrose $(\boldsymbol{\Delta})$ and sucrose-stabilized protoplasts ( $\boldsymbol{\square}$ ) shaken at 120 oscillations/min. All the preparations were suspended in basal medium containing $0.01 \%$ casein hydrolysate together with $5 \mathrm{~mm}$ D-galactose as inducer.

\section{DISCUSSION}

The results of this investigation show that the general characteristics of induction of galactokinase were similar in whole bacteria and protoplasts of Bacillus megaterium although differences were observed in the levels of enzyme and specific activities achieved in the two systems.

The effect of casein hydrolysate supplementation was consistent with the supply of amino acids being a limiting factor during the induction of galactokinase in protoplasts by the nongratuitous inducer D-galactose. On induction of protoplasts with D-fucose, where there was little opportunity for increase in total cellular material due to the unavailability of a metabolizable carbon source, no such limitation was demonstrated.

The higher levels of enzyme and higher specific activities observed in whole bacteria compared with protoplasts was due largely to the greater stability of whole bacteria during the experimental period. This was reflected by their ability to produce enzyme over longer periods. Over shorter time periods, during which protoplasts remain stable, the differences in specific activity appeared to be related to differences in environmental conditions. Evidence in favour of this idea was obtained by incubating whole bacteria in sucrose at the reduced shaking rate necessary to maintain protoplast stability since in these conditions the production of enzyme was reduced to a level similar to that achieved in protoplasts.

Thus, whilst whole bacteria will form greater amounts of galactokinase for longer 
periods of time, the advantages which osmotic fragility confer on protoplasts as a source of a cell-free enzyme-forming system still make them an attractive proposition worthy of further study.

P. J. A. wishes to express his thanks to the Science Research Council for the award of a Research Studentship.

\section{REFERENCES}

BÜRGI, W., RICHTERICH, R. \& BRINER, M. (1967). Ultraviolet photometric determination of total cerebrospinal fluid proteins with a modified biuret reagent. Clinica Chimica Acta 15, 181-184.

Buttin, G. (I963). Mécanismes régulateurs dans la biosynthèse des enzymes du métabolisme du galactose chez Escherichia coli $\mathbf{K} \mathbf{I} 2$. I. La biosynthèse induite de la galactokinase et l'induction simultanée de la séquence enzymatique. Journal of Molecular Biology 7, 164-182.

ButTiN, G. (1968). Les systèmes enzymatiques inductibles du métabolisme des oses chez Escherichia coli. In Advances in Enzymology, vol. 30, pp. 8I-1 37. Edited by F. F. Nord. New York: Interscience.

Coleman, G. \& Ellott, W. H. (1962). Studies on $\alpha$-amylase formation by Bacillus subtilis. Biochemical Journal 83, 256-263.

Coleman, G. \& Elliotr, W. H. (1965). Extracellular ribonuclease formation in Bacillus subtilis and its stimulation by actinomycin D. Biochemical Journal 95, 699-706.

Gulbinsky, S. \& Cleland, W. W. (1968). Kinetic studies of Escherichia coli galactokinase. Biochemistry 7, 566-575.

Kino, Y. \& Rich, A. (1964). Induced enzyme formed on bacterial polyribosomes. Proceedings of the National Academy of Sciences of the United States of America 5I, I I I-I I 8.

LANDMAN, O. E. \& SPIEGelman, S. (1955). Enzyme formation in protoplasts of Bacillus megaterium. Proceedings of the National Academy of Sciences of the United States of America 4r, 689-704.

LAYNE, E. (1957). Spectrophotometric and turbidimetric methods for measuring proteins. In Methods in Enzymology, vol. 3, pp. 447-454. Edited by S. P. Colowick \& N. O. Kaplan. New York: Academic Press.

MCQuillen, K. (1955). Protein, nucleic acid and adaptive enzyme formation in protoplasts of Bacillus megaterium. Journal of General Microbiology 13, iv.

MCQunlen, K. (1960). Bacterial protoplasts. In The Bacteria, vol. I, pp. 249-359. Edited by I. C. Gunsalus \& R. Y. Stanier. New York: Academic Press.

PAIGEN, K. (I963). Changes in the inducibility of galactokinase and $\beta$-galactosidase during inhibition of growth in Escherichia coli. Biochimica et Biophysica Acta 77, 318-328.

Sherman, J. R. \& Adler, J. (1963). Galactokinase from Escherichia coli. Journal of Biological Chemistry 238, 873-878.

WiAME, J. M., StORCK, R. \& VANDERwinkel, E. (1955). Biosynthèse induite d'arabinokinase dans les protoplastes de Bacillus subtilis. Biochimica et Biophysica Acta 18, 353-357.

Wirson, D. B. \& HoGNEss, D. S. (1969). The enzymes of the galactose operon in Escherichia coli. IV. The frequencies of translation of the terminal cistron in the operon. Journal of Biological Chemistry 244, 2143-2148. 